\title{
Philosophical Theology and Christian Doctrines
}

\author{
Maria Rosa Antognazza
}

\begin{abstract}
This contribution discusses Leibniz's views on key Christian doctrines which were surrounded, in the early modern period, by particularly lively debates. The first section delves into his defence of the Trinity and the Incarnation against the charge of contradiction, and his exploration of metaphysical models capacious enough to accommodate these mysteries. The second section focuses on the resurrection and the Eucharist with special regard to their connections with Leibniz's metaphysics of bodies. The third section investigates Leibniz's position on predestination, grace, salvation, and damnation. It comes to the conclusion that salvation, for Leibniz, does not ultimately depend on believing a set of true doctrines, but on a practical attitude: the love of God above all things. Leibniz's theology is thus fundamentally a theology of love which is ultimately practical, and tries to be both universalist and Christian.
\end{abstract}

Keywords: Trinity, Incarnation, Resurrection, Immortality, Eucharist, Transubstantiation, Real Presence, Predestination, Election, Grace, Salvation, Damnation, Pagans, Soteriology

In paragraph 5 of the "Preliminary Discourse" of the Theodicy, Leibniz writes that "Mysteries can be explained as much as is needed in order to believe them". That is to say, in order for revealed doctrines to be object of belief, there must be at least a confused understanding of what they mean. Moreover, we must "be able to support them against objections; without which we would have no grounds for believing them" (GP VI 52). ${ }^{1}$ Throughout his life, Leibniz engages in a project of philosophical theology aimed at fulfilling these two conditions, focusing on some of the distinctive doctrines of Christianity. On the one hand, he rejects specific charges of

\footnotetext{
${ }^{1}$ See chapter on "Faith and Reason" for a discussion of these points. Unless otherwise stated, translations are my own.
} 
contradiction as a necessary condition for continuing to be epistemically justified in holding these doctrines as true; on the other hand, he proposes some metaphysical models capacious enough to accommodate the claims of revealed theology.

\section{Trinity and Incarnation}

Amongst the doctrines of Christianity, it would be hard to find one more central and distinctive than the dogma of the Trinity, according to which there is only one God in three persons equal and distinct, the Father, the Son, and the Holy Spirit. Directly connected with the dogma of the Trinity is the dogma of the Incarnation, according to which Jesus Christ is true man and true God. In the early modern period, these two fundamental dogmas of Christianity, embraced by the main Christian confessions, came under sustained attack from a rapidly spreading anti-Trinitarian movement which rejected them as irrational. For his part, Leibniz endorses these doctrines as truths above reason, endeavouring to defend them against charges of contradiction while proposing his own possible explanations. ${ }^{2}$

Leibniz's defence of the doctrine of the Trinity intends to show that arguments attempting to prove its contradictoriness are not conclusive. It is crucial to note that the aim is not to provide positive arguments in support of the possibility of the Trinity, but purely to demonstrate that anti-Trinitarian arguments fail. This is sufficient to allow the claim that the Trinity can legitimately be presumed to be possible (that is, not irrational, not contradictory) until the contrary is proved. More specifically, Leibniz defends the Trinity from the charge of inconsistency with the logical principle quae eadem sunt eidem tertio sunt eadem inter se (those which are identical to a third are identical to each other) - a principle directly derived from the principle of non-contradiction and which, therefore, cannot admit any exception.

In De Trinitate, a text penned around 1685, Leibniz explains:

That principle that those which are identical to a third are identical to each other, if identity is taken with the greatest rigor, has a place in divine matters no less than in natural affairs. When we say "the father is God" and "the son is God," and "God is One [Unus est Deus]," both father and son, surely the father and the son are identical, unless

\footnotetext{
${ }^{2}$ See for instance De Deo Trino, A VI iv 2291: “There are three persons of the Divinity, of whom there is one essence in number. We do not demonstrate this Mystery of faith by reason, but we only illustrate it and defend it against objections."
} 
"God" in the first two propositions is understood as a person of the Godhead and in the last one as the divine nature or the absolute singular substance that we call God. (A VI iv 2346)

The logical problem Leibniz is referring to in this passage is the formally valid expository syllogism: 'This God is the Father; this God is the Son; therefore the Father is the Son' - a syllogism which was routinely mentioned in Trinitarian discussions from John Duns Scotus to the sixteenth century. ${ }^{3}$ Leibniz's strategy is to show that once the logical structure of the premises is properly exposed, the syllogism fails.

This result is achieved through a fine-grained analysis of a proposition such as "an A is B”. Already in one of his earliest texts, the Defensio Trinitatis of 1669, Leibniz endorses the analysis proposed by the German logician Johannes Raue. ${ }^{4}$ According to Raue, in ordinary language propositions such as Homo est animal, the proper or formal copula -formed by est, a demonstrative pronoun $(i l l e, i d, \ldots)$ and a relative pronoun (qui, quod ...) -is omitted. The est which appears in the proposition is in fact a material (as opposed to a formal) part of the proposition, belonging to the predicate term (est animal). Logical analysis shows that the proposition should be read as having two terms (or material parts) - Homo or the subject term; est animal or the predicate term - which are both predicated of a common third term (commune tertium). ${ }^{5}$ This commune tertium is the subject of both the subject term and the predicate term. The function of the pronouns (ille, qui...) is to refer to the common third term. The formal copula is the logical operator which unites the subject term and the predicate term precisely by stating the sameness of the subject of the subject term and the subject of the predicate term. ${ }^{6}$

\footnotetext{
${ }^{3}$ See Simo Knuuttila, "Trinitarian Fallacies, Identity and Predication," in Trinitarian theology in the Medieval West, edited by Pekka Kärkkäinen (Helsinki: Luther-Agricola-Society, 2007), pp. 72-87.

${ }^{4}$ See Defensio Trinitatis, A VI i 518-530 and Johannes Raue, Subita et Necessaria Defensio adversus Sex Primas Lectiones V. Cl. Joh. Scharfii (Rostock, 1636); Prior Fundamentalis Controversia pro Logica Novissima (Rostock, 1638).

${ }^{5}$ Raue, Subita et Necessaria Defensio, pp. 125-6 and Prior Fundamentalis Controversia pro Logica Novissima, pp. 385-7.
}

${ }^{6}$ Raue, Prior Fundamentalis Controversia pro Logica Novissima, pp. 166-7: "Every one to whom being a philosopher is attributed, is the same one to whom being a student of nature is attributed. Here those things which are attributed are two terms and that to which they are attributed is the common Third Term. To this 
Moreover, Raue notes that quantitative signs (signa quantitativa) such as omnis (all, every), quicunque (whoever), and nullus (none), include the demonstrative pronouns ille, is, ... which are also formal parts of the proposition omitted in ordinary language. ${ }^{7}$ Finally, in syllogistic propositions, singular propositions should be analysed as universal. As Leibniz puts it in the Defensio Trinitatis: "all singular propositions are, by virtue of a hidden sign [e.g. omnis], universal ... for example, if the signs and copula are rightly placed, this proposition, Peter the Apostle was the first Roman Bishop, is formulated thus: Everyone who is Peter the Apostle was [the first] Roman Bishop." (A VI i 520). ${ }^{8}$

Once the proposition Homo est animal is formally analysed, it will be reformulated as follows (using bars to separate the proposition's parts): Omnis qui / est homo / est is, qui / est animal. The logical copula which appears in this formulation expresses the extensional sameness of the subject of predication. In other words, the sameness of A and B expressed by the proposition 'an A is B' means that A is said of a thing and B is said of the same thing (the commune tertium); both $\mathrm{A}$ and $\mathrm{B}$ are predicated of the same subject or commune tertium. ${ }^{9}$

Leibniz applies this analysis to Trinitarian formulations, ${ }^{10}$ noting for instance in $D e$ lingua philosophica: "in the Trinity these two are different: 'to be God the father,' and 'to be he who is [illum qui est] God the father.' For God the son is not God the father, and yet he is the very one who is [est ille ipse qui est] God the father, namely the one most high God." (A VI iv 889) The same type of analysis is behind Leibniz's claims in De Trinitate: "When it is said that 'the same one who is [idem ille qui est] the father is also the son,' the meaning is that in the same absolute substance of God there are two relative substances differing in

common third term the Term of the Predicate is therefore attributed because indeed the Term of the Subject is attributed to it." See also Knuttila, “Trinitarian Fallacies, Identity and Predication,” pp. 71-2.

${ }^{7}$ Raue, Prior Fundamentalis Controversia pro Logica Novissima, pp. 403-4.

${ }^{8}$ Cf. Raue, Subita et Necessaria Defensio, p. 154: “When it is commonly said, He who [Ille, qui] redeems us is our Messiah. This means: Everyone who [Omnis Ille, qui] redeems us, etc. Indeed it means that the Universal sign is omitted."

${ }^{9}$ See Knuttila, “Trinitarian Fallacies, Identity and Predication,” pp. 72-4, who notes a precedent in Peter Aberlard. Intensional sameness would mean, instead, that A and B are synonyms standing for the same thing (ibid., p. 74).

${ }^{10}$ See Leibniz's reformulations of the syllogisms proposed by a leading anti-Trinitarian of the day, Andreas Wissowatius, throughout the Defensio Trinitatis. For a detailed comment see Maria Rosa Antognazza, Leibniz on the Trinity and the Incarnation: Reason and Revelation in the Seventeenth Century (New Haven: Yale University Press, 2007), esp. pp. 20-30. 
number from one another." (A VI iv 2346) Likewise, in De Deo Trino (1680-1684), he explains:

The most powerful of the objections is this: if three [entities] are different from one another, and any one of them is God, it follows that there are three Gods. For if the father is God, and the son is God, and the Holy Spirit is God, and the father is not the son, nor the Holy Spirit; and the Son is not the father or the Holy Spirit, and lastly the Holy Spirit is not the father or the son; either it will have to be said that there are three gods or that we do not know what one and many mean, and therefore in just such a manner it may even be denied that father, son, and grandson are three men; or, the reason will have to be adduced as to why we call these three men, and deny that those are three gods. We shall reply, although the father is not the son, yet the father is he who is [est is qui est] the son, namely, the one God in number. This cannot be said of two men, father and son, and this is the real reason for the difference. (A VI iv 2291-2)

In other texts, Leibniz claims that the apparent contradiction of Trinitarian formulations "is taken away by a distinction", ${ }^{11}$ namely the distinction (common in Protestant scholastic theology) between Deus absolute seu essentialiter sumtus ('God' taken in an absolute or in an essential sense) and Deus relative seu personaliter sumtus ('God' taken in a relative or a personal sense). ${ }^{12}$ Leibniz notes that in the propositions "the Father is God, the son is God, the Holy Spirit is God," the word 'God' has a different sense than the word 'God' which appears in the proposition "only one is God [Unus est Deus]." The former means Deus relative seu personaliter sumtus; the latter means Deus absolute seu essentialiter sumtus. Although Deus relative seu personaliter sumtus and Deus absolute seu essentialiter sumtus refer really to the same entity, they cannot be substituted for one another salva veritate because they appear in contexts which "concern not the thing but the mode of conceiving it"

\footnotetext{
${ }^{11}$ Circa Geometrica Generalia, in Massimo Mugnai, Leibniz’ Theory of Relations (Stuttgart: Steiner, 1992), p. 147. Cf. also Origo Animarum et Mentium (A VI iv 1461): "There is no contradiction in these matters, because men do not sufficiently consider what is identity and diversity [idem et diversum]."

12 See Notationes Generales, A VI iv 552-553; De Trinitate, A VI iv 2346; Circa Geometrica Generalia, in Mugnai, Leibniz' Theory of Relations, p. 147; Remarques sur le livre d'un Antitrinitaire Anglois, A IV v 51; Nouveaux Essais, A VI vi 498;Theodicy, GP VI 63-64. For a discussion of the main texts see Antognazza, Leibniz on the Trinity and the Incarnation, pp. 71-3.
} 
(non de re sed modo concipiendi agitur). ${ }^{13}$ Similarly, in his defence of the mystery of the Incarnation from the charge of contradiction, Leibniz employs reduplicative operators (quatenus, qua) to distinguish between the different senses in which the term 'Christ' is used. What is said of Christ qua God cannot be substituted salva veritate to what is said of Christ qua man, and vice versa. ${ }^{14}$ As Leibniz clarifies in De Persona Christi:

it can be said that a man is omnipresent in the same way as it can be said that a poet treats diseases, if the same man is also a doctor. Let it be understood in a sound way, that is, that he who is [eum qui est] a man, though not qua man, but qua God, is omnipresent, and that he who is [eum qui est] God was born of a virgin, but not inasmuch as he is God [non qua est Deus]. For we speak of the Divine or human nature in Christ according as Divine or human attributes are ascribed to the Christ. ${ }^{15}$

It should be noted that when Leibniz uses reduplicative operators in Trinitarian contexts, ${ }^{16}$ or writes of 'God' taken absolutely versus 'God' taken relatively, no modalism is implied. The point he is making is a purely defensive one, namely, that the Trinitarian formulations under scrutiny are not formally inconsistently when read in opaque contexts. He is not making substantive metaphysical claims about reducing the Trinity to different modes of presentation of God (i.e. as Father, as Son, as Holy Spirit).

Assuming Leibniz is successful in clearing the Trinity and the Incarnation of charges of contradiction, how does he propose to explain these two mysteries "as much as is needed in order to believe them"? As any Christian thinker wishing to remain within the boundaries of orthodoxy, Leibniz is well aware of the need to avoid the two opposite dangers of modalism and tritheism. Orthodoxy requires a combination of monotheism with some real subsistence of the divine persons. Leibniz's distinctive proposal is to talk of three relative substances constituting - "so to speak" (ut sic dicam) -- one absolute substance. In the Examen Religionis Christianae, written in 1686, he states: "They are therefore three related singular

\footnotetext{
${ }^{13}$ See Notationes Generales, A VI iv 552-3.

${ }^{14}$ Cf. Defensio Trinitatis, A VI i 521.

${ }^{15}$ A VI iv 2296. Note that also in this case Leibniz employs the analysis which refers to a commune tertium.

${ }^{16}$ Cf. Defensio Trinitatis, A VI i N. 16; De Persona Christi, A VI iv N. 405; Examen Religionis Christianae, A VI iv 2364, 2368.
} 
substances, one absolute [substance] which contains them [all] and the same individual nature of which is communicated to the singular substances." (A VI iv 2365) To prevent suspicions of tritheism, he is eager to add that each divine person "essentially involves relation." No divine person could exist on its own and together they constitute "an absolute substance single in number". ${ }^{17}$

Pressed some years later by his nephew (a student of theology in Leipzig) about the tritheistic flavour of defining the divine person as "essentially relative intelligent singular substances", Leibniz resorts to a more prudent formulation, shifting from an account of what the persons are to an account of how they are understood by us: "they are understood through incommmunicable relative modes of subsisting [per modos subsistendi relativos incommunicabiles]"18 Notwithstanding this concession, it is apparent that Leibniz regards a more traditional conception of the divine person as "subsisting relations" as inadequate to account for the robust subsistence required by orthodoxy. ${ }^{19}$ Indeed, he pushes back on his nephew's proposal to describe a divine person as a "mode of subsisting." If one wants to avoid the term "substance", Leibniz insists, it should at least be clear that "modes of subsisting" or "relations" are not the persons themselves but that through which ("per quid") the persons are constituted. ${ }^{20}$ This is consistent with the weak ontological status of relations in Leibniz's metaphysical thought. In his framework, as a purely mental entity, a relation could hardly have the ontological status required by an orthodox reading of the Trinity. It is a measure of the earnestness of his engagement with Trinitarian theology that Leibniz is not

\footnotetext{
${ }^{17}$ See Examen Religionis Christianae (A VI iv 2365) and De Scriptura, Ecclesia, Trinitate (A VI iv 2289).

${ }^{18}$ See A I xi 228, 234 and 312.

${ }^{19}$ Cf. Thomas Aquinas, Summa Theologiae, Textum Leoninum (Rome 1886-87; now available online in Corpus Thomisticum), I, q. 29. a. 4: "a divine person signifies a relation as subsisting."

${ }^{20}$ See for instance A I xi 311: "But since in divine matters these things are distinguished better by our mode of understanding than the thing itself, perhaps you could abstain from both and say: several persons in the same absolute singular substance in number are understood by means of several relative incommunicable modes of subsisting in it [per plures in ea modos subsistendi relativos incommunicabiles]. I willingly add the mention of relative and absolute, on account of the reasons which are there manifest. Moreover, in my opinion it would be more cautious to say so, than if you say that the persons [of the Trinity] are modes, making of them modal or incomplete entities, and at the same time you will also avoid formulations which may seem too concrete and still obtain the thing itself, when you express all that through which [per quid] a person is constituted." In 1708 Leibniz writes that the divine persons are constituted per relationes ("through relations") (Ad Christophori Stegmanni
} Metaphysicam Unitariorum, in Nicholas Jolley, “An Unpublished Leibniz MS on Metaphysics,” Studia Leibnitiana 7/2 (1975), pp. 161-189 (here p.188). 
simply prepared to endorse more traditional formulations to avoid trouble, but continues to labour at a model which would, by his own lights, genuinely preserve the dogmatic requirements.

The risk of tritheism, however, can also hardly be denied in a model envisaging three relative substances. In 1708, responding to the attacks of an anti-Trinitarian, Leibniz stresses that only the subsistens absolutum (absolute subsistent) can properly be called substance. ${ }^{21}$ The divine persons, therefore, are said to be substances only in a loose sense of the word. The difference between absolute substance and relative substance seems to be that the latter cannot exist on its own due to its "essential relation" to the other persons. The Trinity seems therefore to be conceived as a concrete, complex system, implying constituents but not parts. $^{22}$

But what should one make of these notions of relative versus absolute substance in the context of Leibniz's metaphysics? If we turn to the notion of a possible world, it seems that also in this case we have a complex system the strong unity of which results from essential relations of everything to everything. Leibniz even uses strikingly Trinitarian language to describe this universal harmony, calling it on occasion the "perichōrēsis of all things". ${ }^{23}$ Such an analogy between a possible world and the individual substances which constitute it, on the one hand, and the absolute versus relative substances of which Leibniz speaks in the case of the Trinity, on the other, seems to yield (at least prima facie) a frankly Spinozistic picture.

The difference between the two cases, however, is significant. In the case of an individual substance, there is no metaphysical impossibility preventing it existing on its own as a "world apart". The fact that there is no solitary monad is down to moral necessity rather than metaphysical necessity. Metaphysically, the proper substance remains the individual substance rather than the world. In the case of the Trinity, Leibniz seems to indicate (in line with orthodoxy) that the impossibility for each person to exist without the others is instead metaphysical. Hence, it is only the subsistens absolutum which is properly a substance namely, the "absolute substance which is only one in number, but which involves [complectitur] three persons of the Godhead" (A VI iv 2364).

\footnotetext{
${ }^{21}$ See Ad Christophori Stegmanni Metaphysicam Unitariorum, p. 188.

${ }^{22}$ See R. M. Adams, "Review of Maria Rosa Antognazza's Trinità e Incarnazione," in The Leibniz Review 10 (2000) p. 57.

${ }^{23}$ See Tractatio de Deo et Homine (1702), GP III 34-35, and LDB 188. Traditional Trinitarian theology employs the notion of perichōressis to indicate the reciprocal inexistence and compenetration of the divine persons.
} 
The same balancing act between the requirements of orthodoxy and the attempt to provide a metaphysically consistent model, is apparent in Leibniz's account of the mystery of the Incarnation. Throughout his life, Leibniz endorses the traditional analogy between the union in Christ of divine and human natures and the union in a human being of mind and body. Likewise, he constantly endorses the orthodox requirement of a substantial union of the two natures into one single person, that is, one subsistence (hypostasis), or one substantial being. Conversely, together with a range of traditionally heterodox ways of explaining this union, Leibniz rejects the doctrine of the communicatio idiomatum, that is, the communication of properties between the human and the divine nature of Christ. Despite its favour with Lutheran theologians, Leibniz is adamant that a communicatio idiomatum cannot be accepted because, in his view, it implies contradiction. True to his claim that a contradictory doctrine can only be false, he does not hesitate to part company, on this point, with many of his fellow Lutherans. $^{24}$

Amongst his own attempts to provide an explanation of the Incarnation, the most ambitious goes back to his early years. In a writing of 1669-1670, De Incarnatione Dei, the young Leibniz proposes to interpret in terms of a hypostatic union both the union of divine and human natures in Christ and the union of mind and body in human beings. ${ }^{25}$ With the evolution of his metaphysics, this ingenious youthful model is abandoned. What is never abandoned, however, is the orthodox requirement driving the model, namely the need for a substantial union. Leibniz constantly maintains that Christ is not an "Ens per aggregationem [Being by aggregation]" 26 but enjoys a true unity, the unity of the person - that is to say, the

\footnotetext{
${ }^{24}$ See for instance De Persona Christi (A VI iv 2296): "the attributes and operations of one Nature are not to be attributed to the other nature ... and certainly it seems contradictory to attribute the things that are proper to one nature to the other".

${ }^{25}$ The theological doctrine of the hypostatic union, according to which two natures - human and divine - are substantially united in Christ in one single person or subsistence (hypostasis), was established by the Council of Chalcedon (451 CE). In De Incarnatione Dei, Leibniz defines the hypostatical union as "the action of a thing having in itself the principle of action immediately through another thing [actio rei principium actus in se habentis immediatè per rem aliam]" (A VI i 534). For a detailed discussion of De Incarnatione Dei see Antognazza, Leibniz on the Trinity and the Incarnation, pp. 35-41.

${ }^{26}$ See De Persona Christi (A VI iv 2295).
} 
intrinsic unity of a substantial being. ${ }^{27}$ On the other hand, especially in his later years and in the correspondence with Bartholomew Des Bosses, it becomes increasingly doubtful whether his mature metaphysics has the resources to fulfill this requirement. Finally giving up his exploration with Des Bosses of a vinculum substantiale, or substantial bond, superadded to monads, Leibniz candidly admits: "Nor do we need any other thing besides Monads and their modifications, for Philosophy as opposed to the supernatural. But I fear that we cannot explain the mystery of the Incarnation, and other things, unless real bonds or unions are added." 28

The problem Leibniz is grappling with is whether in the framework of his monadology any composite being could be granted, with metaphysical rigour, the status of substance. Of course he often writes of corporeal substances; but can aggregates of monads unified by a dominating monad really be regarded as endowed with the intrinsic unity needed for substantiality? In so far as Christ is an even more complex composite being, the problem is exacerbated. It is not, however, a problem unique to the Incarnation. Quite the opposite: it affects all the traditional primary substances of a broadly Aristotelian metaphysics. Leibniz seems to remain conspicuously unconcerned about ensuring that his metaphysical system has the resources for granting the status of substances to plants, animals, and embodied human beings. He seems in fact content with the thought that the dominating monad of these composite beings is a substance, without any pressing need to account for a substantial union with the changing body (that is, aggregate of subordinate monads) that always accompany it. In the case of the Incarnation, however, there is a requirement for substantial union that his monadological model cannot explain. Leibniz does not deny the possibility of such a stronger union as a truth above reason, but finally retreats from his youthful ambition of providing a positive metaphysical model (however imperfect) of the Incarnation. ${ }^{29}$

\section{Resurrection and Eucharist}

\footnotetext{
${ }^{27}$ See Symbole et Antisymbole des Apostres, in Maria Rosa Antognazza, "Inediti leibniziani sulle polemiche trinitarie," in Rivista di filosofia neo-scolastica 83/4 (1991): 535-538, p. 538; Il n'y a qu'un seul Dieu, A VI iv 2211; De Scriptura, Ecclesia, Trinitate, A VI iv 2291; De Persona Christi, A VI iv 2294-2297.

${ }^{28}$ LDB, 276-278. Trans. by R. M. Adams in Leibniz: Determinist, Theist, Idealist (Oxford: Oxford University Press, 1994), p. 304.

${ }^{29}$ For a more detailed discussion of this issue see Maria Rosa Antognazza, “Leibniz's theory of substance and his metaphysics of the Incarnation," in Locke and Leibniz on Substance and Identity, edited by Paul Lodge and T.W.C. Stoneham (Abingdon - New York: Routledge, 2015), pp. 231-252 (esp. pp. 238-245).
} 
Two further core doctrines of the Christian tradition directly connected with the metaphysics of bodies are the resurrection and the Eucharist. In the framework of Leibniz's philosophy, the resurrection of bodies turns out to be remarkably easy to explain and, at the same time, remarkably at odds with the intentions of this traditional doctrine. According to tradition, the dead will be resurrected on the day of the Last Judgement, when our immortal souls will be reunited with our bodies. Underpinning this doctrine is a philosophical anthropology according to which the human being is not merely an immortal soul accidentally united to a mortal body for a limited period of time. If this were the case, the immortality of the soul would be sufficient to account for human beings' everlasting life without needing the postulation of a bodily resurrection bound to arouse all sorts of awkward philosophical problems. Instead, deeply ingrained in the Jewish and Christian tradition is the view that embodiment is an essential constituent of human beings. Also in the changed circumstances of heavenly life, the immortal soul which continues to live while our mortal earthly body decays, does not constitute, on its own, our human nature. Therefore, soul's immortality is not sufficient to ensure the preservation of our full identity. The nature and identity of a human being can be fully restored only through her/his resurrection as an embodied being. A crucial consequence of this view is that our earthly death is a real death, a real dissolution of a human being, as opposed to a transformation (however drastic) of the way of life of an immortal self. Furthermore, a proper resurrection (as opposed to a reincarnation) requires that human beings "will rise again with their own bodies which they now bear," as opposed to any odd body. ${ }^{30}$

While Scripture does not enter into much detail as to how one might think of this bodily resurrection, from early on the challenge for philosophical theology has been to provide an account which can answer (at the least to some extent) some obvious philosophical questions. The Apostolic Creed's formulation, according to which there will be a "resurrection of the flesh," has traditionally been taken as a claim that also the mortal aspects of our nature ('the flesh') will come to life again. Already Paul clarifies, however, that the resurrected body will be a 'transfigurated' body, namely a 'glorious' or even a

\footnotetext{
${ }^{30}$ Cf. Lateran Council IV (1215) in Denz-Schönm, 801 (Enchiridion symbolorum. Edited by H. Denzinger. Revised by A. Schönmetzer).
} 
'spiritual' body ${ }^{31}$ that, unlike our earthly, corruptible, coarse body of flesh and bones, will be endowed with immortality. To those who ask: "How are the dead raised? With what kind of body do they come?" Paul replies:

What you sow does not come to life unless it dies and what you sow is not the body which is to be, but a bare kernel ...what is sown is perishable, what is raised is imperishable ... the dead will be raised imperishable ... For this perishable nature must put on the imperishable, and this mortal nature must put on immortality. (1 Cor 15:35$37,42,53)$

Needless to say, this Pauline doctrine leaves plenty of open questions for the scores of theologians of all stripes who tackled them down the centuries.

Leibniz bravely enters the fray as early as May 1671 with a letter to Duke Johann Friedrich, and a brief essay sent with it on the resurrection of bodies (De Resurrectione Corporum).$^{32}$ In both the letter and the essay, Leibniz seems to take his cue from Paul's notion of "a bare kernel" to speculate about a metaphysical model according to which in "everything" (that is, not only in human beings and animals, but also in vegetables and minerals) there is a "kernel of substance [Kern der substantz]" (A II $^{2}$ i 175) or a "certain selfdiffusing seminal centre" (A $\mathrm{II}^{2}$ i 185). This kernel is "so subtle, that it remains also in the ashes of burned things, and can, as it were, draw itself into an invisible centre" (A II ${ }^{2}$ i 175). ${ }^{33}$ In the course of his letter and essay, Leibniz employs also the expressions punctum saliens, "fountain of life," and "flower of substance" to indicate the survival of a subtle, indestructible bodily kernel or bodily essence capable of retreating into a point ( $\mathrm{A} \mathrm{II}^{2} \mathrm{i} 184-5$ and $\mathrm{A} \mathrm{II}^{2} \mathrm{i}$ 175). ${ }^{34}$ In turn, this point is further qualified in his letter to the Duke as a "physical point"

\footnotetext{
${ }^{31}$ Cf. Phil 3:21: "Dominum Iesum Christum, qui transfigurabit corpus humilitatis nostrae, ut illud conforme faciat corpori gloriae suae" and 1 Cor 15:44: "seminatur corpus animale, resurgit corpus spirituale".

${ }^{32}$ A II i 108-9, 115-6 (pp. 175, 183-5 of the new edition).

${ }^{33}$ See also A $\mathrm{II}^{2}$ i 185.

${ }^{34}$ Lloyd Strickland's careful discussion in "Leibniz, the 'flower of substance', and the resurrection of the same body" (The philosophical forum 40 (2009), 3: 391-410) traces these notions to the alchemical tradition. See also his helpful study on "The doctrine of "the resurrection of the same body' in early modern thought" (Religious studies 46 (2010): 163-183). A discussion of Leibniz's early pieces on the resurrection is offered by Christia Mercer in Leibniz's Metaphysics: Its Origins and Development (Oxford: Oxford University Press, 2001), pp. 284-288 and "Leibniz, Matter, and the Metaphysics of the Resurrection," in Einheit in der Vielheit. VIII.
} 
serving as "an instrument and as though a vehicle of the soul" which is "constituted in a mathematical point" (A $\mathrm{II}^{2}$ i 176). From this point -- in which also the soul is supposed to be somehow "implanted" (A II $^{2}$ i 184) -- a human being can unfold again at the moment of the resurrection.

The metaphysical picture painted by Leibniz in these youthful texts is heavily indebted to alchemical notions and far from straightforward. However, despite its immaturity and strange details, the thought behind this model seems to be clear enough. Our earthly visible bodies, Leibniz reasons, "are in perpetual flux" (A II ${ }^{2}$ i 184). Even here on earth, our identity therefore does not depend on the preservation of the same coarse matter. Given that, following Paul's teaching, the body is due to be resurrected as a "spiritual body," the restoration of the same gross body is not a requirement for our bodily resurrection. ${ }^{35}$ The survival of an indestructible kernel or flower of bodily essence, united in an invisible point with our soul and capable of unfolding again, is therefore sufficient to preserve the identity of a human being and to explain the resurrection.

During the following years, the evolution of Leibniz's metaphysics of bodies leaves behind the musings about alchemical bodily spirits and essences which characterize these early pieces. Rather than fully abandoning his youthful model, however, Leibniz's mature metaphysics seems to breathe new life into the idea of a constant flux of the body and of its withdrawal into an involute minimal state from which it can unfold and develop again at the resurrection. By 1703, Leibniz thinks of the body as an aggregate of indestructible, mind-like simple substances or monads, unified by a dominant monad (that is, in human beings, the mind). ${ }^{36}$ In created beings, this dominant monad is always 'embodied', namely, it is always accompanied by a changing aggregate of monads represented by the dominant monad as its

Internationaler Leibniz-Kongress, edited by H. Breger, J. Herbst and S. Erdner, vols 1-2 (Hanover: LeibnizGesellschaft, 2006), vol. 2, pp. 601-605.

${ }^{35}$ Leibniz's phrase “corpus spirituale resurgere debet” (A II ${ }^{2}$ i 184) echoes 1 Cor 15:44: "resurgit corpus spirituale".

${ }^{36} \mathrm{Cf}$. the fivefold ontological scheme presented by Leibniz in his letter to De Volder of 20 June 1703 (GP II 252; trans. by Adams in Leibniz, p. 265): "I distinguish therefore (1) the primitive Entelechy or Soul, (2) Matter, i. e. primary matter, or primitive passive power, (3) the Monad completed by these two, (4) the Mass [Massa] or secondary matter, or organic machine, for which countless subordinate Monads come together, (5) the Animal or corporeal substance, which is made One by the Monad dominating the Machine." 
body ${ }^{37}$ Death is merely a regression into a state of stupor or unconsciousness similar to the state of all "bare" monads which enjoy no apperception or distinct representations. ${ }^{38}$ It is easy enough to see how monads can be awoken from this slumber. At the resurrection they will resume (and presumably greatly improve) their distinct perceptions: they will even grow their bodies again - that is to say, they will perceive more distinctly the changing aggregate of mind-like simple substances which they represent as their bodies.

In his final years, Leibniz is explicit in linking his views on the constant 'embodiment' of created simple substances with the 'glorious body' envisaged by the Christian tradition:

why could not the soul always keep a subtle body, organized in its own way, which could even one day resume what is needed of its visible body in the resurrection, since a glorious body is granted to the blessed, and since the ancient fathers have granted a subtle body to angels. ... Because, as regards the beatific vision of the blessed souls, this is compatible with the functions of their glorified bodies, which will not fail to be organic in their own way. ${ }^{39}$

At the same time, he claims to see "no reason why some particular secondary matter should be perpetually attached to [the soul] until the resurrection" (LDB 78-79) -- by which he seems to mean that there is no reason for the aggregate of monads which the soul represents as its body to remain the same, as opposed to being in constant flux.

In sum, Leibniz's mature metaphysics appears to be uniquely well placed to give content to Paul's claim that our resurrected bodies will be "spiritual bodies”. In Leibniz's monadological framework, all bodies ultimately reduce to "spiritual" bodies, that is, aggregates of mind-like simple substances. Claiming that they can rise again no longer seems to pose a problem. The price to be paid for such a neat picture is, however, very high, indeed

\footnotetext{
${ }^{37}$ Cf. Principles of Nature and of Grace (GP VI 598-599): “each distinct simple substance or monad, which forms the centre of a composite substance (for example, of an animal) and the principle of its oneness, is surrounded by a mass composed of an infinity of other monads, which constitute the body belonging to this central monad". In his fifth piece for Samuel Clarke, Leibniz writes: "there are no created substances entirely destitute of matter. Because I hold, in agreement with the Ancients and with reason, that the angels or Intelligences, and the souls separated from a gross body, have always subtle bodies despite their being themselves incorporeal." (GP VII 406)

${ }^{38}$ Cf. Monadology $\S ~ 21,23-24$ (GP VI 610-1).

${ }^{39}$ Considerations sur la doctrine d'un Esprit Universel Unique, 1702 (GP VI 529-538, here pp. 533, 536).
} 
so high that it arguably does away with the very doctrine which is supposed to be neatly explained. As Leibniz himself proudly notes in some remarks of 1712, amongst the accomplishments of his theory of substance there is the "banishment of death." 40 Unfortunately for him, it was not long before other thinkers pointed out the "scandalous" nature of this very "banishment." 41 If all substances are ultimately indestructible and hence immortal, one can hardly envisage a genuine resurrection -- at any rate, not the robust kind of resurrection which presupposes (as in the traditional Christian doctrine) the reality of death as the dissolution of a human being not reducible to her/his immortal soul. The closest substitute Leibniz offers for the notion of natural mortality is the mere metaphysical possibility of a supernatural annihilation of created monads by God. Moreover, in Leibniz's monadological framework, there seem to be no resources for turning the ideal unification of an aggregate of simple substances into a substantial union holding together a being one per se. Although also for Leibniz a human being is not merely a disembodied soul or mind, it is this soul or mind which, strictly speaking, qualifies as a substance. Since there is no real metaphysical union with the changing aggregate of monads which always accompanies it, the soul or mind is also, arguably, our true (and immortal) self.

A related set of problems challenges Leibniz's reflection on the mystery of the Eucharist, for the explanation of which he experiments with the controversial notion of vinculum substantiale briefly mentioned above. Rather than a late entry into his own metaphysical toolkit, the vinculum substantiale is a metaphysical hypothesis that Leibniz considers offering to his Catholic friend, Des Bosses, as an addition to the theory of monads. The need for such an addition is precipitated by Leibniz's eventual acknowledgement that monads and monadic domination are insufficient for a satisfactory account of theological doctrines such as Eucharistic transubstantiation. Given that, as a Lutheran, Leibniz was not committed to transubstantiation (that is, to a change of substance while the appearances of bread and wine remain unchanged), one may think that the problem was confined to maintaining the good

\footnotetext{
${ }^{40}$ GP III 430. On 23 August 1713, Leibniz writes to Des Bosses: "as you know, I deny that not only the soul but also the animal dies" (LDB 318-9).

${ }^{41}$ These later debates are discussed in Matteo Favaretti Camposampiero, “The Ban of Death: Leibniz's Scandalous Immortalism" (forthcoming). Favaretti Camposampiero identifies the dissertation by Elias Camerarius (1673-1734) De morte in exilium acta as the work introducing the phrase exilium mortis Leibnitianum ("the Leibnizian banishment of death") used to indicate Leibniz's controversial views on death. I am grateful to Favaretti Camposampiero for sharing with me a draft of his illuminating study.
} 
will of the Catholic side towards his metaphysical theories, rather than being an issue which really demanded, in his view, a satisfactory solution. Accordingly, Leibniz frankly points out to his friend that Lutherans only need to account for the real presence of Christ's body, not for transubstantiation. ${ }^{42}$ On closer inspection, however, the problems raised by transubstantiation expose more general problems about the ability of Leibniz's theory of monads to account for the existence of genuine corporeal substances, as well as for mysteries to which he was committed (such as the Incarnation).

Leibniz's first stab at explaining to Des Bosses how his monadology could accommodate transubstantiation is to suggest that "when the monads constituting the bread are destroyed with respect to their primitive active and passive powers, and the presence of the monads constituting Christ's body is substituted for them, there remain only the derivative forces that were in the bread exhibiting the same phenomena that the monads of the bread had exhibited." (LDB 152-3) Des Bosses appreciates the similarity of this proposal to the doctrine of "real accidents" employed by Catholic theologians to explain transubstantiation, namely, the claim that there can be "absolute" or non-modal accidents which remain in the Eucharist without a subject. He questions, however, the consistency of this view with Leibniz's metaphysical system. Since derivative forces are conceived as modifications of primitive forces, how can they remain when the latter are destroyed? (LDB 158-9).

Leibniz is quick to see the point. He abandons the suggestion of a destruction of monads and their primitive forces, trying instead a different tack. In his letter to Des Bosses of 15 February 1712, the hypothesis of a "real unifier superadded to monads by God" is introduced. This first version of the vinculum substantiale appears to envisage some kind of bond holding together the simple substances which compose a corporeal substance, thereby bestowing the unity a corporeal substance would require if it has to be "something real over and above monads" (LDB 224-5). The idea is that transubstantiation no longer rests on the destruction of monads. Since a corporeal substance depends on the presence of this substantial bond, in order to create a new corporeal substance it is enough for God to

\footnotetext{
${ }^{42}$ Leibniz to Des Bosses, 8 September 1709 (LDB 152-3): "for us there is no place for either transubstantiation or consubstantiation of the bread, but only that Christ's body is perceived at the same time that the bread is received, so that the presence alone of Christ's body must be explained". For an insigthful and detailed discussion of transubstantiation and the vinculum substantiale in the context of Leibniz's metaphysics of bodies, see the introduction by B. Look and D. Rutherford to their edition of the Leibniz-Des Bosses correspondence (LDB lvii-lxxii).
} 
substitute one vinculum with another. ${ }^{43}$ Leibniz's problems, however, are far from over. The vinculum cannot be merely a relation, given that relations for him are mental entities, namely, second order truths resulting from the simultaneous consideration of two or more individuals with their properties. The bond envisaged by Leibniz's proposal clearly needs to have some substantial status of its own: it needs to be, in Leibniz's own phrase, a substantial bond or a "unifying reality, which adds something absolute (and therefore substantial), albeit impermanent, to the things to be unified." (LDB 226-7)

In later letters, the character of substance (as opposed to relation) of the vinculum takes over, ${ }^{44}$ until his final account of the substantial bond suggests a conception of corporeal substance much closer to the model of traditional Aristotelian substances than his theory of monads and monadic domination would allow. Corporeal substance is now identified with the substantial bond itself. Writing on 13 January 1716, Leibniz notes that the "primary matter and substantial form" of the Scholastics, "namely the primitive active and passive powers of the composite, and the complete thing resulting from these, are really that substantial bond that I am urging". His reasoning seems to be that if there has to be composite substances, they must contain "something substantial beside monads; otherwise ... composites will be mere phenomena." (LDB 364-5) In other words, to be genuine substances, corporeal substances would need to be "substantial bonds" resulting from primary matter and substantial form as in the Aristotelian-Scholastic model. "Therefore," Leibniz concludes, "my doctrine of composite substance seems to be the very doctrine of the Peripatetic school, except that their doctrine does not recognize monads. But I add them" (LDB, 365). The problem is, however, that the model of monads and monadic domination "does not cohere well enough" with the real or metaphysical unification required for "the raising of phenomena to reality, that is, composite substances," (LDB 340-1) and needed in turn to explain transubstantiation. So much Leibniz himself confesses to Des Bosses in a letter of June 1715 .

All in all, Leibniz's attempt to explain transubstantiation within his monadological framework seems to end in failure. His metaphysical theories meet, however, with greater success in accounting for the versions of the Eucharistic doctrine which matter to Lutherans, namely the real presence, and the multi-presence in different places, of Christ's body. The doctrine of real presence agrees with transubstantiation in maintaining that the body of Christ

\footnotetext{
${ }^{43}$ Cf. LDB 226-227 and lxiii.

${ }^{44} \mathrm{Cf}$. the letter to Des Bosses of 20 September 1712 and LDB lxviii.
} 
is substantially present in the Eucharistic, but does not claim that only the 'accidents' of bread and wine, and not the substance, are left. In his own words, what Leibniz needs to explain is how "one and the same Body of Christ ... is really present, by its substance, wherever the Eucharistic sacrificial offering [Hostia] is." $" 45$

Leibniz's solution hinges on the application to the specific case of the Eucharist of his general conception of the substance of body as consisting in a force, or a principle of action, as opposed to extension. ${ }^{46}$ In a letter of January 1692 to the former Huguenot and Catholic convert, Paul Pellisson-Fontanier, he maintains that "it is not only in the Eucharist but everywhere else, that bodies are present only by this application of primitive force to the place". ${ }^{47}$ That is, according to Leibniz, the local presence of a substance consists in some sort of immediate operation. A substance is present where it operates immediately. Although this operation, and therefore presence, is naturally limited to one place, there is no reason why a substance could not supernaturally operate immediately, and therefore be present, in many places. Substantial presence by operation is the way in which Christ is really multi-present in all the places in which the Eucharist is celebrated. ${ }^{48}$

\section{Predestination, Grace, Salvation, and Damnation}

Another central debate characterizing Christian theology from Luther's reformation onward is the issue of predestination. The doctrine of predestination stands at the intersection of a number of key Christian doctrines, notably, the notion, role, and distribution of divine grace as regards salvation and damnation; the concept of election; the issue of justification and its relationship to faith and good works. Controversies de auxiliis (that is, regarding the divine aids available to humankind) became a locus classicus of seventeenth-century theology,

\footnotetext{
${ }^{45}$ De Demonstratione possibilitatis Mysteriorum Eucharistiae, c. autumn 1671; A VI i 515. Trans. by Adams in Leibniz, p. 353.

${ }^{46}$ See the excellent discussion by Adams, Leibniz, pp. 349-360, from which I am drawing.

${ }^{47}$ A I vii 249.

${ }^{48}$ Adams, Leibniz, esp. pp. 358-360 shows that this same fundamental strategy was employed by Leibniz for some forty years, and that it is already to be found in its key elements as early as 1668 in $D e$

Transsubstantiatione (A VI i N. 15/2). For the historical and theological background to Leibniz's discussions of the Eucharist see Irena Backus, Leibniz Protestant Theologian (Oxford: Oxford University Press, 2016), pp. 954. On De Transsubstantiatione cf. also Christia Mercer, Leibniz's Metaphysics: Its Origins and Development (Cambridge: Cambridge University Press, 2001), pp. 82-89.
} 
marking sharp divisions not only between Catholics, Lutherans (or Evangelicals), and Reformed churches, but also inside these Christian denominations. ${ }^{49}$ The distinction between alternative positions is typically drawn along the lines of a different balance between two competing concerns of Christian theology: on the one hand, the essential role played in salvation by God's grace (blocking the Pelagian view that human beings can redeem themselves by dint of good works); on the other hand, the role of human beings' response to God's grace (blocking worries about God's arbitrariness and injustice in saving some but not others independently of a human response to His offer of redemption).

Amongst the most harshly contested issues in the Protestant camp was the so-called doctrine of double predestination, espoused by Calvinists following the teaching of Calvin's successor in Geneva, Theodor Beza (1519-1605). According to Beza, from all eternity God has decreed not only who will be saved but also who will be damned, in contrast to the common view held by Lutheran churches according to which there is predestination to salvation but not to damnation. By the early seventeenth century, the Calvinist or Reformed churches further divided themselves between those denying any role to human beings' response to grace in determining their salvation, and those upholding the role of human free will in resisting a salvific grace which is offered to all. Whereas for the former God saves only those he has elected independently of their merits or demerits, for the latter God wants the salvation of all but some human beings condemn themselves but refusing God's grace. The Synod of Dordrecht (1618-19) sealed the victory of hard-line Calvinists who endorsed double predestination through an absolute decree issued by God after the Fall, against the universalist position on grace held by the opposing party, the Arminians, named after the Dutch Reformed theologian, Jacobus Arminius (1560-1609).

Leibniz engages intensively with the issue of predestination, especially in the late 1690 's and early 1700's, in the context of the negotiations for the unification of the Lutheran church of Hanover with the Reformed church of Brandenburg. ${ }^{50}$ In the same period, he also

\footnotetext{
${ }^{49}$ On these debates see for instance Agustín Echavarría, "Leibniz on the Efficacy and Economy of Divine Grace," in Tercentenary Essays in the Philosophy and Science of G. W. Leibniz, edited by L. Strickland, J. Weckend, E. Vynckier (Palgrave Macmillan, forthcoming 2016) and Backus, Leibniz Protestant Theologian, esp. pp. 57-73. Leibniz strongly prefers to refer to his own denomination as "Evangelical" rather than "Lutheran", to avoid any perceived sectarianism.

${ }^{50}$ See Antognazza, Leibniz, pp. 308-406 and Backus, Leibniz Protestant Theologian, pp. 61-8. Of special importance is an extensive text of 1699 written by Leibniz in collaboration with the Lutheran abbot of Luccum,
} 
comments extensively on Gilbert Burnet's exposition of article 17 of the Thirty-Nine Articles of the Church of England, devoted to "Predestination and Election". ${ }^{51}$ Leibniz's focal point is an attempt at mediation, in the framework of his philosophy, between those stressing the absolute decree of God in freely determining election versus those stressing God's consideration of human beings' responses to grace. In his view, these positions can be to some extend harmonized by maintaining that God's decree to create the world eternally entails the simultaneous considerations of all the factors which enter into the best of all possible worlds, including the interconnection between God's free election and the response of individuals to grace.

At any rate, Leibniz aligns himself with the view of all Christian denominations in regarding grace as an essential factor in salvation. More specifically, already in the Discourse on Metaphysics of 1686, he follows tradition in distinguishing between different types of grace. ${ }^{52}$ This taxonomy is further clarified in his later comments on Burnet:

Aids of grace are either efficacious (i.e., absolutely effective [Effectricia]) or merely sufficient. Effective aids are effective infallibly, but the considerations of efficacity and infallibility are distinct. Sometimes aids have efficacity per se and in virtue of their own nature. And aids have efficacity that is either complete, so that they cannot be thwarted

Gerhard Wolter Molanus (Unforgreiffliches Bedencken über eine Schrift genandt "Kurtze Vorstellung”; A IV vii N. 79).

${ }^{51}$ Gilbert Burnet (1643-1715), Bishop of Salisbury and leading representative of theological latitudinarianism, published in 1699 an Exposition of the Thirty-Nine Articles of the Church of England, that is, a detailed commentary on the official doctrine of the Anglican Church summarized in the Thirty-Nine Articles promulgated in 1571 by the Archbishop of Canterbury and Queen Elisabeth I. Leibniz's own commentary on Article 17 was finished by 1705 but remained unpublished during his life-time. It is edited, translated, and introduced by Michael J. Murray in G. W. Leibniz, Dissertation on Predestination and Grace (New Haven: Yale University Press, 2011) (hereafter DPG, followed by page).

${ }^{52}$ See Echavarría's illuminating discussion in "Leibniz on the Efficacy and Economy of Divine Grace," to which I am indebted. In the Discourse on Metaphysics, Leibniz writes (A VI iv 1577-8; AG 62): “This grace of God, whether ordinary or extraordinary, has its degrees and its measures; in itself, it is always efficacious in producing a certain proportionate effect, and, further, it is always sufficient, not only to secure us from sin, but even to produce salvation, assuming that man unites himself to it by what derives from him. But it is not always sufficient to overcome man's inclinations, for otherwise he would have nothing more to strive for; this is reserved solely for the absolutely efficacious grace which is always victorious, whether it is so by itself or by way of appropriate circumstances." 
by contrary circumstances (as they appear to have been in the miraculous conversion of Paul), or sub modo, because they are not in fact impeded by contrary circumstances. By contrast, aids have efficacity per accidens (so to speak) if they derive it from assisting circumstances. Only those that have complete per se efficaciousness have per se infallibility. Others derive their infallibility from the circumstances, which either do not impede, or, in general, assist and thus are per accidens (so to speak) (not with respect to God, but with respect to the thing). And finally, certain [aids] are not efficacious, but merely sufficient, for concerning the one who wills, an outcome is lacking where the will fails. (DPG, 46-49; trans. modified)

The main distinction here, endorsed also by Leibniz, is the well-established one between (objective) sufficient grace and (subjective) efficacious grace. Leibniz embraces a universalist position according to which sufficient grace is given to all. ${ }^{53}$ That is to say, with his antecedent or absolute will, God wants all to be saved and gives to all sufficient grace to resist sin. This grace, however, does not obtain in all the same effects due to the different circumstances in which human beings find themselves, and their response to these circumstances. In theological terms, although all are granted sufficient grace, whether this grace is efficacious in leading to salvation depends also on human beings' responses to their varying circumstances. It remains open to God, however, to bestow a special type of efficacious grace which is always per se infallible. ${ }^{54}$

Given that the efficacy of grace normally depends, for Leibniz, also on the circumstances dictated by the order which governs the best of all possible worlds, it hardly need to be said that, in the context of his strict determinism, the usual problems raised by the relationship between grace and human responsibility become particularly acute. In his early

\footnotetext{
53 Theodicy $§ 95$ (GP VI 155).

${ }^{54}$ Donald Rutherford proposes a naturalized conception of grace according to which God's grace, for Leibniz, "may be nothing more than his choice of external circumstances" (see Donald Rutherford, "Leibniz and the 'Religion of Reason',' in Für unser Glück oder das Glück anderer, edited by Wenchao Li (Hildesheim: Olms, 2016), vol. 3, pp. 365-376 (here p. 373) and "Justice and Circumstances: Theodicy as Universal Religion," in New Essays on Leibniz's Theodicy, edited by Larry M. Jorgensen and Samuel Newlands (Oxford: Oxford University Press, 2014), pp. 71-91). Although acknowledging the key role played by circumstances in Leibniz's account of grace, Echavarría resists identification (see "Leibniz on the Efficacy and Economy of Divine Grace").
} 
Confessio Philosophi (1672-1673) Leibniz shows himself intensely aware of the pressure put by the "lament of the damned" on his theodicy project:

this inexorable difficulty is placed before us, whatever sophistry we may employ: the apparent justice of the lament of the damned, that they were born in such a way, sent into the world in such a way, came upon such times, persons, and occasions that they were not able not to perish; their minds, occupied prematurely by vicious thoughts, existed in circumstances that favored evil, that stimulated evil; they lacked circumstances that would have released them, that would have restrained them, as if the fates conspired in the ruin of the wretched ... they curse the series of the universe, which also involves them. ${ }^{55}$

A central plank of Leibniz's defence of God's justice is the claim that He loves everyone. But how can this claim be maintained if there are people who are eternally damned? A possible reply is that "of course evil men damn themselves ... since they are forever impenitent and turn away from God." 56 Damnation is conceived by Leibniz as a persistent dissatisfaction with the state of things, a dissatisfaction which is in turn identified with "a burning hatred of God ... in which consists the nature of despair" (A VI 3, 118; Sleigh 35):

Whoever dies malcontent dies a hater of God. And now he follows along the road on which he began, as if he were headed for the precipice; and not being held back by external things, since access to his senses has been closed off, he nourishes his soul, which has withdrawn into itself, with that hatred of things already begun, and with that misery and disdain, and with indignation, envy, and displeasure, all of them increasing more and more. (A VI iii 142; Sleigh 91)

\footnotetext{
55 A VI iii 136-7; Sleigh 77. I am grateful to Lucy Sheaf for drawing my attention to this passage. The importance of the issue of eternal damnation for Leibniz's theodicy is lucidly highlighted in Lucy Sheaf, Eternal Damnation in Leibniz's Early Theodicy (King's College London, 2013; MPhilSt thesis).

${ }^{56}$ Preface to Ernst Soner's book on eternal punishment (1708), LH 1, 20 Bl. 194 (draft); trans. by Lloyd Strickland in Leibniz on God and Religion (London: Bloomsbury, 2016), p. 326.
} 
Leibniz is careful to stress that punishment consists in nothing else than this very hatred of God persistently chosen by the sinner. Moreover, the infinity of the sinner's punishment is justified by the perpetual continuation of his sinning:

even if we should concede that no sin is infinite in itself, it can still be said that the sins of the damned are infinite in number, because they persist in sin throughout all eternity. Therefore if sins are eternal, it is just that the punishments should be eternal too. ${ }^{57}$

And yet the eternally damned seem to have a point in continuing to blame their circumstances. Had circumstances been significantly different, they too would not have sinned. In a text of 1689-90 Leibniz squarely faces this complain (A VI, 4, 1639): "You will insist that you can complain. Why did God not give you more strength? I reply, If He had done that, you would not exist, for He would have produced not you but another creature". 58 Fair enough, one could see the damned replying, but it would still have been better not to exist at all than enduring eternal misery. How can one claim that God loves also me in particular if I exist in the series of things which cannot but include my infinite unhappiness?

There can be little doubt that the doctrine of eternal damnation poses (to use his own phrase) an "inexorable difficulty" to Leibniz. However, it is debatable whether Leibniz was really committed to it. ${ }^{59}$ To be sure, there are numerous passages in which the doctrine is endorsed, but it has been noted that this endorsement stems from a pragmatic approach to revealed theology, rather than an explicit commitment to the truth of eternal damnation: it is safer, Leibniz suggests, to continue to maintain this traditional doctrine since it can serve to

\footnotetext{
${ }^{57}$ Preface to Ernst Soner's book; trans. by Strickland in Leibniz on God and Religion, p. 326. Interestingly, despite the rejection of purgatory typical of Protestants, Leibniz shows sympathy for this doctrine, involving a limited period of after-death punishment that leads, eventually, to eternal happiness (see Lloyd Strickland, “Leibniz's Philosophy of Purgatory,” in American Catholic Philosophical Quarterly 84/3 (2010), pp. 531-548). ${ }^{58}$ Mentes ipsae per se dissimiles sunt inter se (c. March 1689-March 1690); Sleigh xl.

59 The controversy goes all the way back to the eighteenth century, when Johann August Eberhard argued in his Neue Apologie des Sokrates (1772) that Leibniz secretly embraced universal salvation while Gotthold Ephraim Lessing maintained that Leibniz was an advocate of eternal punishment (Leibniz von den Ewigen Strafen, 1773). This debate has been rejuvenated by Lloyd Strickland "Leibniz on Eternal Punishment," in British Journal for the History of Philosophy 17/2 (2009), 307-331, Robert M. Adams, "Justice, Happiness, and Perfection in Leibniz's City of God," in New Essays on Leibniz's Theodicy, pp. 197-217 (see esp. pp. 207-213), and Paul Lodge, "Eternal Punishment, Universal Salvation and Pragmatic Theology in Leibniz," in Tercentenary Essays in the Philosophy and Science of G. W. Leibniz.
} 
deter people from sinning. ${ }^{60}$ On the other hand, he also expresses doubts about the actual usefulness of this doctrine in preventing sin, as well as dismay at the readiness with which some theologians regard the damnation of others as an edifying thought:

Mr Arnauld ... finds it strange that so many millions of pagans have not been condemned; I would find it much stranger if they had been: I don't know why we are so inclined to believe that people are damned or sunk in eternal miseries, even if they could not help it; but this leads to thoughts hardly compatible with the goodness and justice of God ... I don't believe that the opinion of the eternal damnation of so many virtually innocent people is so edifying and so useful in preventing sin as is imagined. It leads to thoughts hardly compatible with the love of God. (A I vi 107-8)

Certainly, in his own positive account of salvation, Leibniz takes a remarkably liberal view on whom can be saved, extending this possibility to people of all religions and also to pagans. For the salvation of an individual, he writes in 1690-1691, "no revealed article is absolutely necessary, and therefore it is possible to be saved in every Religion, provided that one truly loves God above all things" ${ }^{61}$ In the earlier Dialogue entre Poliandre and Theophile, written in the mid-1679, he claims that "those who love God above all things are in a condition [en estat] to be saved." In the Propositiones Theologicae of 1685 - 1686 he explains that: "No one can be justified without a true love of God". 62 "Nor," Leibniz clarifies in the Nouveaux Essais,

${ }^{60}$ See Leibniz to Lorenz Hertel (January 1695), A I xi 21 (cited by Adams, "Justice, Happiness, and Perfection in Leibniz's City of God", see esp. pp. 216-217).

${ }^{61}$ A I vi 78-79. Cf. also Leibniz's marginal note on his copy of the fourth part of Paul Pellisson-Fontanier's Reflexions sur les différends de la religion (Paris, 1691) (A I vi 101). Leibniz is keen to stress that this is also the view held by many Roman Catholic theologians, notably the Jesuits. Cf. Theodicy, § 96 (GP VI 156): "the Roman Church, going further than the Protestants, does not absolutely damn those who are outside its communion, and even outside Christianity ... I will content myself with naming Father Friedrich Spee, the Jesuit, one of the most excellent men of his Society, who was also of this common view regarding the efficacy of the love of God"; NE 500: "many eminent doctors of the Roman Church, far from damning lax Protestants, have been willing to save even pagans"; A I vi 94: "The Jesuits have maintained that invincible ignorance excuses, and that therefore the sincere conscience of anyone is always the last judge down here, in conscientiae foro." See also Theodicy, § 95 (GP VI 156), quoted below.

${ }^{62}$ Respectively A VI iv 2220 and A VI iv 2355. Trans. by Adams, "Justice, Happiness, and Perfection in Leibniz's City of God", p. 205. 
are those who accord salvation to pagans, or to others who lack the ordinary aids, thereby obliged to rely for this on natural processes alone ... One can, after all, maintain that, when God gives them grace sufficient to call forth an act of contrition, he also gives them before their death, even if only in the final moments, all the light of faith and all the fervour of love which they need for salvation; this being given to them either explicitly or dispositionally, but in any case supernaturally. ${ }^{63}$

In De Salvatione Ethnicorum, written by 1698 , he maintains that it is false that pagans can be saved without Christ "because no one is able to love God above all things except he who understands that this is the greatest good to him, but no one understands this except a Christian." However, "if we imagine that there has been a love of God above all things in any of the pagans," the person who loved in this way would be saved - albeit not merely through natural powers. Leibniz's point is not that pagans cannot be saved but that anyone who loves God above all things (and is therefore saved) can do so only through grace mediated by Christ. ${ }^{64}$ At the beginning of the text he affirms in fact that in some cases pagans can be "granted pure grace through Christ". ${ }^{65}$ As the passage from the Nouveaux Essais suggests, divine grace works in mysterious ways. For all that we know, it could be given at death, including to pagans. ${ }^{66}$

Grace is thus necessary for salvation but the key point is, for Leibniz, that "God never refuses his grace to those who seek it with a good heart". ${ }^{67}$ In support of this thesis he quotes the sentence, "facienti quod in se est Deus non denegat gratiam,"68 calling on the authority of

many theologians strongly approved in the Roman Church itself who taught that a sincere Act of love of God above all things suffices for salvation, when it is aroused by

\footnotetext{
${ }^{63}$ Nouveaux Essais, book IV, chap. xviii, § 9; NE 502. See also NE 500 and Dialogue entre Poliandre and Theophile, c. mid-1679 (A VI iv 2220-2221) and Theodicy, § 95 (GP VI 155-6).

${ }^{64}$ A IV vii 666: "Any one is able to fear God by his natural powers, but no one can love him except by grace through Christ."

${ }^{65}$ A IV vii 666-7; trans. by Strickland in Leibniz on God, pp. 323-4.

${ }^{66}$ See also Dialogue entre Poliandre et Theophile (A VI iv 2220-2222, 2226).

${ }^{67}$ Mémoire pour des Personnes éclairées (A IV iv 615; PW 105).

${ }^{68}$ See Leibniz's marginal note on his copy of the fourth part of Pellisson's Reflexions (A I vi 144); Theodicy, $\S$ 95 (GP VI 155); and Dialogue entre Poliandre et Theophile (A VI iv 2221).
} 
the grace of Jesus Christ. Father Francis Xavier replied to the Japanese that if their ancestors had used well their natural lights, God would have given them the necessary graces to be saved, and the Bishop of Geneva, Francis of Sales, strongly approves this reply (Book 4 of the love of God chap. 5). (Theodicy § 95; GP VI 156)

In sum, salvation for Leibniz does not ultimately depend on believing a set of true doctrines, but on a practical attitude: the love of God above all things. To be sure, the best way to achieve this aim is to reach a true knowledge of God, since truly knowing God can only lead to loving him. But also those whose knowledge is very imperfect can be saved, since a sincere love of God is sufficient for salvation. ${ }^{69}$ Leibniz acknowledges that the ability to love in this way requires the support of divine grace and the mediation of Christ. But he also maintains, most importantly, that such grace is given in a mysterious manner to all those who search God with a sincere heart, ${ }^{70}$ whether or not they realize its being mediated through Christ and the Holy Spirit. Leibniz's theology is thus fundamentally a theology of love which is ultimately practical, ${ }^{71}$ and tries to be both universalist and Christian. Overall, it is strongly driven by soteriological considerations. What really matters is to be saved, that is, achieve the dynamic state of eternal happiness or beatitude which consists in contemplating, and therefore loving, God's perfection.

\footnotetext{
${ }^{69} \mathrm{Cf}$., for instance, Dialogue entre Poliandre et Theophile (A VI iv 2226): "Let us return to what is more certain, namely, that we must love God above all things, and our neighbour as ourselves. It is in this that the law consists. It is in this, with the addition of the doctrine of Jesus Christ, that the true active faith also consists ... let us agree with the Evangelist and Apostle St. John, who does not preach anything other than this charity full of faith and this divine love which shines out through good works, and we will have done enough to be saved". ${ }^{70}$ Cf. Theodicy $\S 95$ (GP VI 155-6): "I would be rather in favour of those who grant to all human beings a sufficient grace ... for how do we know whether they do not receive ordinary or extraordinary aids which are unknown to us?"

${ }^{71}$ Leibniz's conception of theology as a theology of love, and its practical nature, are stressed by Robert M. Adams in "Justice, Happiness, and Perfection in Leibniz's City of God"; "Leibniz's Conception of Religion," in The Proceedings of the Twentieth World Congress of Philosophy, edited by Mark D. Gedney, vol. 7: Modern Philosophy (Philosophy Documentation Center, 2000), pp. 57-70; and "Leibniz's Examination of the Christian Religion," in Faith and Philosophy 11/4 (1994), pp. 517-46. See also Maria Rosa Antognazza, "Theory and Praxis in Leibniz's Theological Thought," in G. W. Leibniz im Lichte der Theologien, edited by Irena Backus, Wenchao Li, and Hartmut Rudolph (Stuttgart: Steiner, forthcoming 2016).
} 
Maria Rosa Antognazza is Professor of Philosophy at King's College London. Her publications include Leibniz on the Trinity and the Incarnation: Reason and Revelation in the Seventeenth Century (Yale University Press 2007); Leibniz: An Intellectual Biography (Cambridge University Press 2009; winner of the 2010 Pfizer Award); and Leibniz: A Very Short Introduction (Oxford University Press 2016). 